\title{
Foraging dichotomy in loggerhead sea turtles Caretta caretta off northwestern Africa
}

\author{
E. Eder ${ }^{1,2, *}$, A. Ceballos ${ }^{1}$, S. Martins ${ }^{3}$, H. Pérez-García ${ }^{3}$, I. Marín ${ }^{1}$, A. Marco ${ }^{3}$, \\ L. Cardona ${ }^{1}$
}

${ }^{1}$ Department of Animal Biology and IRBio, Faculty of Biology, University of Barcelona, Avenida Diagona 643, 08028 Barcelona, Spain

${ }^{2}$ Centro Nacional Patagónico (CENPAT-CONICET), 9120 Puerto Madryn Chubut, Argentina

${ }^{3}$ Estación Biológica de Doñana-CSIC, c/ Americo Vespucio s/n, 41092 Sevilla, Spain

\begin{abstract}
A foraging dichotomy among sexually mature females has been reported for several populations of loggerhead sea turtles, where large adult females forage primarily in neritic habitats and smaller adult females forage primarily in oceanic habitats. The prevalence of neritic foragers has been considered a consequence of much higher food availability in neritic foraging grounds than in oceanic habitats. However, previous satellite tracking suggested that oceanic foraging is prevalent among the adult females in Cape Verde. We used stable isotopes to assess the actual proportion of neritic and oceanic females in this population and used carapace length, clutch size and egg volume to assess differences in their fitness. Stable isotope ratios confirm that the adult female population in Cape Verde is dominated by oceanic foragers that avoid the oligotrophic region west of the archipelago. The proportion of oceanic and neritic foragers did not depart significantly from that expected if turtles settled opportunistically between the archipelago and mainland Africa at the end of their developmental migration, without any preference for the continental shelf. However, adult neritic foragers had a higher fitness, as revealed by larger carapace length and clutch size. Furthermore, they were older than adult oceanic foragers, thus indicating that some animals shifted from oceanic to neritic habitats with age, most likely due to a higher accumulated probability of detecting the African shelf over time. In conclusion, most of the females nesting in Cape Verde do not select the best available foraging grounds, but settle opportunistically in the highly productive area between the archipelago and Africa when they return from their developmental migration.
\end{abstract}

KEY WORDS: Sea turtles $\cdot$ Foraging strategies $\cdot$ Stable isotope analysis $\cdot$ Cape Verde

\section{INTRODUCTION}

Optimality has long been the dominant paradigm in foraging ecology, and intraspecific differences in resource use have been considered a direct consequence of phenotypic differences (Brown 2001, Gilchrist \& Kingsolver 2001). Ideal free distribution models were developed under this paradigm and assumed that wild animals exploiting heterogeneous landscapes selected the most suitable foraging patches based on knowledge of landscape heterogene- ity (Stephens \& Krebs 1986). Even foragers with limited sensory detection ranges, exploiting ecosystems where food patches are unevenly and unpredictably distributed, have been hypothesized to concentrate in optimal habitats. The basis of this hypothesis is that the reorientation jumps characteristic of Lévy walks become shorter and less frequent in food-rich patches, thus offering a simple mechanistic model for optimal foraging (Sims et al. 2008, Humphries et al. 2010). However, entire populations of species purposed to use Lévy walks during foraging (Hays et al. 
2006, Sims et al. 2008) may concentrate in extremely food-poor habitats and avoid nearby food-rich regions without any obvious reason (Shillinger et al. 2008), thus challenging the hypothesis that large marine vertebrates always exploit the most profitable habitats they encounter.

The loggerhead sea turtle Caretta caretta is the most abundant sea turtle in the subtropical and warm temperate regions of the world and has a complex life cycle characterized by long migrations spanning entire oceans and different types of habitats (Bolten 2003). Originally, loggerhead sea turtles were thought to spend their early life in the oceanic domain and then recruit to the neritic zones near their natal areas (Bolten 2003). Recruitment to the neritic habitats was thought to be triggered by improved diving performance and by increasing food demands with age and size that could not be sustained by oceanic resources (Bolten 2003). However, recent research has revealed a more flexible ontogeny of habitat use in loggerhead sea turtles, depending on the environmental conditions and even involving reversible changes (Hatase et al. 2002, Hawkes et al. 2006, McClellan \& Read 2007, Mansfield et al. 2009, McClellan et al. 2010, Rees et al. 2010, Reich et al. 2010, Zbinden et al. 2011).

In most populations, there is a dichotomy in the foraging strategies of adult female loggerhead sea turtles (Hatase et al. 2002, 2007, 2010, Hawkes et al. 2006, Reich et al. 2010, Zbinden et al. 2011). Based on satellite tracking or stable isotope analysis or both, larger adult females may be more likely to be associated with neritic habitats, whereas smaller females appear to be more likely to forage in oceanic habitats. Generally, these less productive habitats are oceanic, but small adult females may sometimes also be found in neritic habitats (Hatase et al. 2002, 2007, 2010, Hawkes et al. 2006, Reich et al. 2010, Zbinden et al. 2011). These differences in size may not be related to differences in age as oceanic and neritic foragers were suggested to reach maturity and begin reproduction at similar ages (Hatase et al. 2010).

As no genetic differences between oceanic and neritic foragers nesting in the same area have been reported to date (Watanabe et al. 2011), they cannot be considered 2 independent populations, rather just the result of phenotypic plasticity. It is probable that turtles exploiting less productive habitats will grow more slowly than turtles exploiting more productive habitats (Hatase et al. 2010; McClellan et al. 2010, Piovano et al. 2011). Furthermore, clutch size is known to increase with female body size (Broderick et al. 2003) and female turtles exploiting the less productive feed- ing grounds, therefore, lay smaller clutches (Hatase et al. 2010, Zbinden et al. 2011). In this scenario, oceanic foraging offers less profitability and reproductive output than neritic foraging, being, therefore, suboptimal. Accordingly, most of the females nesting in Japan, the central Mediterranean and the northwestern Atlantic are neritic (Hawkes et al. 2007, 2011, Hatase et al. 2010, Zbinden et al. 2011). However, the opposite pattern seems to hold for Cape Verde and Oman, although the published information refers only to a handful of satellite-tracked females from each population (Hawkes et al. 2006, Rees et al. 2010).

Whether the prevalence of oceanic foragers in Cape Verde and Oman is true or only a consequence of sampling bias remains unknown, but it is noteworthy that planktonic primary productivity is very high there, relative to that of other oceanic regions inhabited by adult loggerhead sea turtles (Longhurst 1998). This observation suggests that a tendency to remain in oceanic areas could be more profitable there than in other regions, although neritic females from Cape Verde have also been reported to have a larger body size than the oceanic females (Hawkes et al. 2006), which suggests oceanic foraging is suboptimal there also. If a larger sample size confirmed these size differences and the prevalence of oceanic foraging in Cape Verde, an alternative hypothesis would be needed to explain why suboptimal foraging prevails there.

Hatase et al. (2002) proposed an analogy with anadromous salmonids and hypothesized that immature female loggerhead sea turtles encountering rich patches of food settled there and remained oceanic through their life, whereas those experiencing food scarcities during their oceanic stage became neritic. Recent research has demonstrated that at the final stage of their developmental migration, immature loggerhead sea turtles recruit and settle in foraging grounds closer to their natal beaches than those used during earlier developmental stages (Bowen et al. 2005) and once sexually mature, the females appear to have high site fidelity to these feeding grounds (Broderick et al. 2007). In this scenario, immature loggerhead sea turtles approaching Cape Verde at the final stage of their developmental migration through the Atlantic will eventually encounter the food-rich area east of the archipelago generated by a permanent upwelling (Longhurst 1998). It is probable that they will settle there opportunistically, because immature loggerhead sea turtles lack any previous knowledge about the landscape heterogeneity of a region they have not visited before (Monzón-Argüello et al. 2010). If this hypothesis is true, then we can 
offer the following predictions: (1) the proportions of neritic and oceanic loggerhead sea turtles nesting in Cape Verde should not differ from those predicted from the relative area occupied by oceanic and neritic habitats between the Cape Verde archipelago and mainland Africa; (2) clutch size should be smaller in oceanic foragers; and (3) age should not differ between oceanic and neritic adult foragers.

Here, we combine previously published information obtained by satellite tracking (Hawkes et al. 2006) with information on the stable isotope profile of northwestern Africa (Pinela et al. 2010), the concentration of the stable isotopes of carbon and nitrogen in the tissues of nesting females and measurements of carapace length and clutch size to test these predictions.

\section{MATERIALS AND METHODS}

\section{Study area and sample collection}

The Cape Verde Islands are located in the eastern North Atlantic between $14^{\circ} 45^{\prime}-17^{\circ} 18^{\prime} \mathrm{N}$ and $22^{\circ} 38^{\prime}-25^{\circ} 22^{\prime} \mathrm{W}, 500 \mathrm{~km}$ off the coast of Senegal (Fig. 1). The local weather conditions give this tropical region a moderate subtropical climate. The loggerhead nesting season in Cape Verde is prolonged, extending from June through October. This volcanic archipelago hosts the third-largest rookery of loggerhead turtles in the Atlantic (Marco et al. 2012),

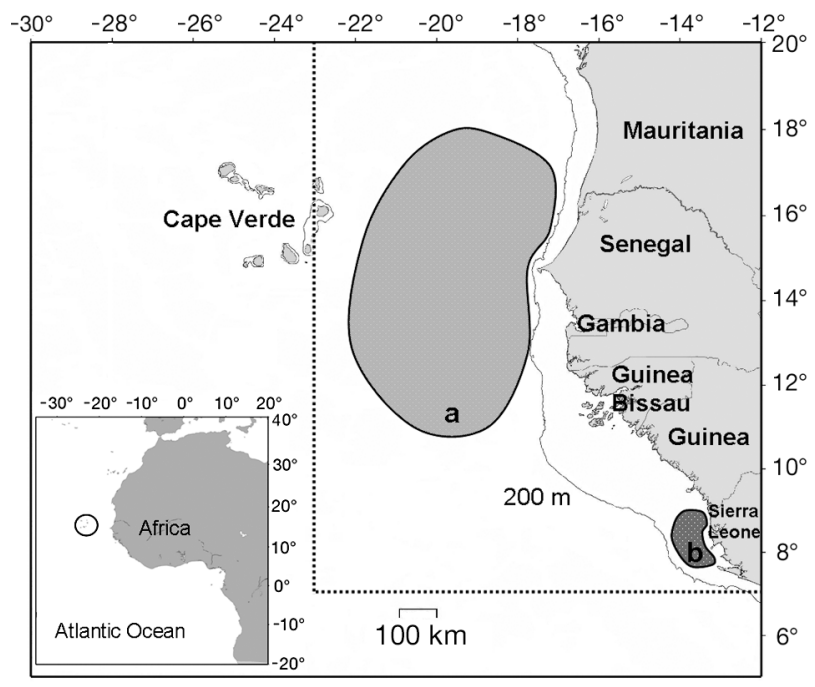

Fig. 1. Map of Cape Verde Archipelago showing (a) oceanic and (b) neritic adult foraging grounds described in Hawkes et al. (2006). Extent of area used to calculate total available oceanic and neritic habitat (see 'Materials and methods') is indicated (dashed line) and the population is reproductively isolated from the other Atlantic loggerhead rookeries (MonzónArgüello et al. 2010). Furthermore, the Cape Verde population constitutes the most endangered regional management unit for this species in the Atlantic (Wallace et al. 2011).

Satellite tracking (Hawkes et al. 2006) suggests that adult females nesting in Cape Verde forage only in the region between the archipelago and mainland Africa and avoid the oceanic habitats to the west. Accordingly, ArcGis 9.3.1 (www.esri.com/software/ arcview/index.html) was used to calculate the area of oceanic (deeper than $200 \mathrm{~m}$ ) and neritic (shallower than $200 \mathrm{~m}$ ) habitat in a region limited by meridian $23^{\circ} \mathrm{W}$ to the west, the African coastline to the east, parallel $20^{\circ} \mathrm{N}$ to the north and parallel $7^{\circ} \mathrm{N}$ to the south.

Samples of humeri (sections distal to the deltopectoral crest) were collected from necropsies of 72 adult females found dead on nesting beaches on Boavista Island during the 2008, 2009 and 2010 nesting seasons. Turtles had been slaughtered illegally by poachers while nesting, so perhaps they may not be representative of the population as a whole, although carapace length distribution fits well that of nesting females (Hawkes et al. 2006). The humeri were dried outdoors and stored without preservatives in plastic bags at ambient temperature $\left(15\right.$ to $\left.25^{\circ} \mathrm{C}\right)$ until analysis. The curved carapace length (CCL) of the females was measured with a fiberglass tape measure $( \pm 0.1 \mathrm{~cm})$. Information on CCL and fecundity was recorded for 66 females on the same island during the 2009 and 2010 nesting seasons. Nesting females were randomly selected on 2 high-density nesting beaches (Ervatao and Ponta Cosme) in the southeastern part of the island. The female CCL was measured during egg laying, and the precise nest location was marked. All nests were excavated after egg laying, and all eggs of every clutch were counted and measured with a digital caliper $( \pm 0.1 \mathrm{~mm})$. Fecundity was assessed in terms of the size of the clutch (number of eggs per nest), egg diameter and clutch volume. Clutch volume, a variable that represents fecundity or reproductive success, was estimated based on the volume of each egg in a nest. The egg volume was approximated by the volume of a sphere $\left(4 / 3 \pi r^{3}\right.$, where $r=$ diameter $/ 2$ ).

\section{Stable isotope analysis}

Subsamples of the outer part of the bone were removed from the humeri samples with a manual 
saw, then dried in a stove at $60^{\circ} \mathrm{C}$ for $24 \mathrm{~h}$ and powdered with a mortar. The lipids were removed by rinsing the powdered subsamples several times with a 2:1 chloroform:methanol solution (Bligh \& Dyer 1959). The subsamples were then treated for decarbonation with a $0.5 \mathrm{M}$ hydrochloric acid (HCl) solution (Bocherens et al. 1997, Newsome et al. 2006). Demineralization with $\mathrm{HCl}$ may affect the nitrogen signature (Bunn et al. 1995). For this reason, bone samples were previously subsampled for the $\mathrm{N}$ signature without the $\mathrm{HCl}$ treatment and for the $\mathrm{C}$ signature after decarbonation. One $\mathrm{mg}$ of sample was used for $\mathrm{N}$ determination, and 0.5 to $0.7 \mathrm{mg}$ of sample was used for C determination. The samples were weighed in tin cups (3.3 to 5 $\mathrm{mm}$ ) combusted in a continuous-flow isotope-ratio mass spectrometer (Flash 1112 IRMS Delta C Series EA, Thermo Finnigan). Atropine was used as a standard system check for the elemental composition of carbon and nitrogen. The samples were processed at Serveis Cientificotècnics de la Universitat de Barcelona.

Isotopic composition was expressed in the standard $\delta$ notation in parts per thousand (\%) relative to predefined international standards, V-PDB (Vienna Pee Dee Belemnite) calcium carbonate for $\delta^{13} \mathrm{C}$ and atmospheric $\mathrm{N}_{2}$ (air) for $\delta^{15} \mathrm{~N}$, according to:

$$
\delta X=\left[\left(R_{\text {sample }} / R_{\text {standard }}\right)-1\right] \times 10^{3}
$$

where $X$ is ${ }^{13} \mathrm{C}$ or ${ }^{15} \mathrm{~N}, R_{\text {sample }}$ is the heavy-light isotope ratio of the sample $\left({ }^{13} \mathrm{C} /{ }^{12} \mathrm{C}\right.$ or $\left.{ }^{15} \mathrm{~N} /{ }^{14} \mathrm{~N}\right)$, and $R_{\text {standard }}$ is the heavy-light isotope ratio in the reference standards. The conventional use of these internationally accepted standards with relatively low and high levels of ${ }^{13} \mathrm{C}$ and ${ }^{15} \mathrm{~N}$, respectively, results in negative carbon and positive nitrogen isotope values. The international stable isotope secondary standards of known ${ }^{13} \mathrm{C} /{ }^{12} \mathrm{C}$ ratios, as given by the International Atomic Energy Agency (IAEA), namely polyethylene (IAEA $\mathrm{CH}_{7}, \delta^{13} \mathrm{C}=-31.8 \%$ ), L-glutamic acid (IAEA USGS $_{40}, \delta^{13} \mathrm{C}=-26.3 \%$ ) and sucrose (IAEA $\mathrm{CH}_{6}$, $\delta^{13} \mathrm{C}=-10.4 \%$ ), were used for calibration at a precision of $0.2 \%$. For nitrogen, international stable isotope secondary standards of known ${ }^{15} \mathrm{~N} /{ }^{14} \mathrm{~N}$ ratios, namely, $\left(\mathrm{NH}_{4}\right)_{2} \mathrm{SO}_{4}$ (IAEA N1, $\delta^{15} \mathrm{~N}=+0.4 \%$ and IAEA $\mathrm{N} 2, \delta^{15} \mathrm{~N}=+20.3 \%$ ) , L-glutamic acid $\left(\delta^{15} \mathrm{~N}=\right.$ $-4.5 \%$ ) and caffeine (IAEA $600 \delta^{15} \mathrm{~N}=+0.0 \%$ ), were used to a precision of $0.3 \%$.

The concentration of stable isotopes in the bone of marine mammals from northwestern Africa (Pinela et al. 2010) was used as a benchmark to support the classification of the turtles as 'neritic' or 'oceanic' foragers.

\section{Skeletochronology analysis}

Skeletochronology was used to test the hypothesis that adult neritic and oceanic foragers do not differ in average age. This technique is based on identifying growth layers on bones, assumed to be deposited according to an annual cycle, because bone growth rates vary seasonally and lines of arrested growth (LAGs) are deposited when bone is not growing. Accordingly, the number of growth layers in bone sections is representative of estimated relative age in years. Skeletochronology has been successfully used in several species of sea turtles, where LAGs on bones can be visualized as concentric layers of deposited calcium carbonate in transverse sections (Zug et al. 1986, Bjorndal et al. 1998, Snover \& Hohn 2004, Avens \& Goshe 2007, Piovano et al. 2011). A section of bone approximately 3 to $5 \mathrm{~mm}$ thick was cut from the narrowest part of the diaphysis of the humerus, where the greatest number of periostal growth layers is expected to be retained (Zug et al. 1986). The bone sections were stored in $70 \%$ alcohol for $36 \mathrm{~h}$ and then decalcified in $5 \%$ nitric acid for a minimum of $96 \mathrm{~h}$ (the maximum duration was variable depending on the diameter of the section and the structure of the bone). After decalcification, the bone sections were dehydrated in subsequent dilutions of alcohol of increasing concentration ( $70 \%$ for $12 \mathrm{~h}$ to $1 \mathrm{wk}, 90 \%$ for 6 to $12 \mathrm{~h}$ and $100 \%$ for 6 to $12 \mathrm{~h}$ ). The sections were then embedded in chloroform for 4 to $6 \mathrm{~h}$ at ambient temperature, embedded in a solution of chloroform and paraffin at $25^{\circ} \mathrm{C}$ for 4 to $6 \mathrm{~h}$, and finally fixed in paraffin at $60^{\circ} \mathrm{C}$ for 4 to $6 \mathrm{~h}$. Transverse sections 20 $\mu \mathrm{m}$ thick were cut on an FM AG microtome (model Rotary 3003) and collected on microscope slides. The sections were then stained with hematoxylin and observed at $40 \times$ magnification with a Bausch \& Lomb ${ }^{\text {TM }}$ optical microscope to count the LAGs.

\section{Data analysis}

A multivariate cluster analysis was performed to explore the intrinsic pattern of the $\delta^{13} \mathrm{C}$ and $\delta^{15} \mathrm{~N}$ values of females, including also the isotopic signature of 3 marine mammal species from Pinela et al. (2010) to be used as a reference for neritic and oceanic stable isotope ratios. A nonparametric Mann-Whitney $U$-test was used to compare the $\delta^{13} \mathrm{C}$ and $\delta^{15} \mathrm{~N}$ values, $\mathrm{CCL}$, estimated age and predicted volume of the clutch between adult female loggerhead sea turtles from the 2 main groups of turtles identified by the cluster analysis as oceanic and neritic foragers. A 
regression analysis was performed to explore the relationship between the clutch volume and the CCL of nesting females from previous seasons and to predict the clutch volume from the CCL of adult females from different foraging strategies. Spearman's rank correlation coefficients $\left(\mathrm{r}_{\mathrm{S}}\right)$ were used to quantify the following relationships: clutch volume vs. egg diameter; clutch volume vs. the CCL of nesting females from previous seasons; CCL vs. $\delta^{13} \mathrm{C}_{i} \mathrm{CCL}$ vs. $\delta^{15} \mathrm{~N}_{i}$ CCL vs. estimated age; $\delta^{13} \mathrm{C}$ vs. estimated age; $\delta^{15} \mathrm{~N}$ vs. estimated age; eggs per nest vs. CCL; egg diameter vs. $C_{C L}$ egg diameter vs. clutch size; $\delta^{13} \mathrm{C}$ vs. predicted clutch volume; and $\delta^{15} \mathrm{~N}$ vs. predicted clutch volume. Statistical analyses were conducted using STATISTICA software (StatSoft). The level of significance was set at $p<0.05$. The means are reported with standard deviation unless otherwise stated.

\section{RESULTS}

The adult female loggerhead sea turtles from Cape Verde were clearly clustered in 2 different groups according to their $\mathrm{C}$ and $\mathrm{N}$ isotopic signals (Fig. 2). Ten females were grouped in cluster 1 and showed values $\left(\delta^{13} \mathrm{C}\right.$ of $>-14 \%$ and $\delta^{15} \mathrm{~N}$ of $>13 \%$ ) consistent with the bone isotopic signals of marine mammals foraging on the continental shelf, whereas the remaining 61 females, grouped in cluster 2 , showed values $\left(\delta^{13} \mathrm{C}\right.$ of $<-14 \%$ and $\delta^{15} \mathrm{~N}$ of $<13 \%$ ) close to those of marine mammals known to be typical oceanic foragers (Fig. 2). Accordingly, $14.1 \%$ of the adult female turtles in the sample were classified as 'neritic foragers' and the remaining $85.9 \%$ of the females were considered 'oceanic foragers' (Fig. 3). These proportions did not depart significantly from those expected if turtles had settled randomly in the area between the Cape Verde archipelago and northwestern Africa $\left(\chi^{2}=0.00, \mathrm{df}=1, \mathrm{p}=1.00\right)$, as $85 \%$ of the habitat in the region is deeper than $200 \mathrm{~m}$ and $15 \%$ is shallower (Fig. 1).

The ratios of stable isotopes showed an overlap between the 2 foraging groups, but the neritic turtles had significantly higher $\delta^{13} \mathrm{C}$ and $\delta^{15} \mathrm{~N}$ values $\left(\delta^{13} \mathrm{C}\right.$ Mann-Whitney $U_{10,61}=5.0, \mathrm{p}<0.001 ; \delta^{15} \mathrm{~N} U_{10,61}=$ $2.0, \mathrm{p}<0.001)$. They had larger CCLs than their oceanic counterparts (neritic range 87 to $100 \mathrm{~cm}$ vs. oceanic range 74 to $101.5 \mathrm{~cm}, U_{10,58}=16.0, \mathrm{p}<0.001$; Table 1). Furthermore, the CCL was significantly correlated with the $\delta^{13} \mathrm{C}\left(\mathrm{r}_{\mathrm{S}}=0.37, t_{69}=3.3, \mathrm{p}=0.001\right)$

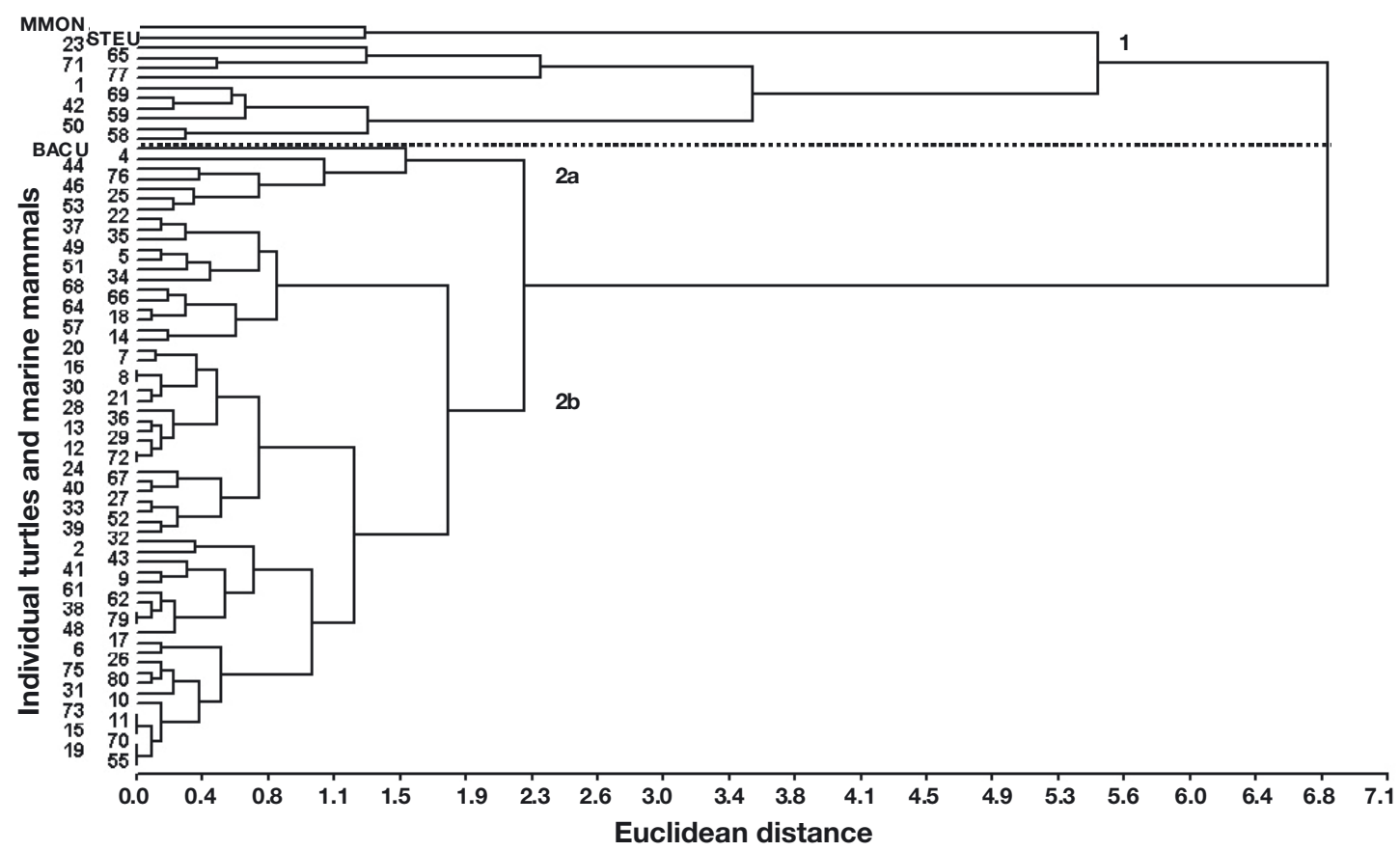

Fig. 2. Caretta caretta. Cluster analysis using isotope values of humeri of adult female loggerhead sea turtles from Cape Verde (Euclidean distances, complete linkage method, cophenetic correlation factor: 0.803). Cluster 1: female turtles enriched in both ${ }^{15} \mathrm{~N}$ and ${ }^{13} \mathrm{C}$ (likely to be neritic foragers). Cluster 2: female turtles depleted in ${ }^{15} \mathrm{~N}$ and ${ }^{13} \mathrm{C}$ (likely to be oceanic foragers). Female turtles included in subgroup 2a were more depleted in ${ }^{13} \mathrm{C}$ and ${ }^{15} \mathrm{~N}$ than those included in subgroup $2 \mathrm{~b}$, probably because the former spend more time to the west of the considered area. Analysis included isotope values of the most onshorebenthic marine mammals (Sousa teuszii [STEU]) and Monachus monachus [MMON]) and the most offshore-pelagic marine mammal (Balaenoptera acutorostrata [BACU]) from northwestern Africa (Pinela et al. 2010) for comparison 


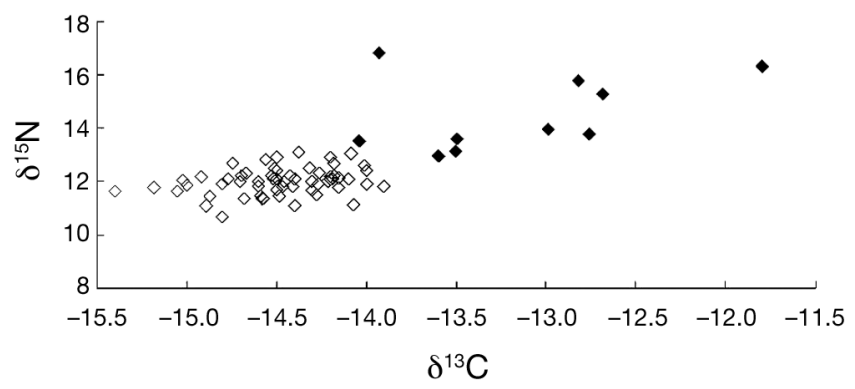

Fig. 3. Caretta caretta. Plot of the $\delta^{13} \mathrm{C}$ and $\delta^{15} \mathrm{~N}$ values in bone of loggerhead sea turtles from Cape Verde. 'Neritic foragers' were those with $\delta^{13} \mathrm{C}>-14.0 \%$ and $\delta^{15} \mathrm{~N}>13.0 \%$ $(\diamond, \mathrm{N}=10)$, while 'oceanic foragers' were those with $\delta^{13} \mathrm{C}<$ $-14.0 \%$ and $\delta^{15} \mathrm{~N}<13.5 \%$ o $(\diamond, \mathrm{N}=61)$

and $\delta^{15} \mathrm{~N}$ values $\left(\mathrm{r}_{\mathrm{S}}=0.45, t_{69}=4.2, \mathrm{p}<0.001\right)$. The oldest turtles in the sample were neritic (14 to 62 lines of arrested growth for neritic turtles, 7 to 31 lines of arrested growth for oceanic turtles), and statistically significant differences were found in the average number of lines of arrested growth for both groups $\left(U_{10,37}=96.0, \mathrm{p}=0.020\right.$; Table 2$)$. However, the number of lines of arrested growth was not correlated with CCL, but was significantly correlated with the $\delta^{13} \mathrm{C}\left(\mathrm{r}_{\mathrm{S}}=0.29, t_{46}=2.0, \mathrm{p}=0.045\right)$ and $\delta^{15} \mathrm{~N}$ values $\left(\mathrm{r}_{\mathrm{S}}=0.29, t_{47}=2.0, \mathrm{p}=0.047\right)$. These results indicated an increased use of neritic habitats with age or, alternatively, a longer survival of turtles in neritic habits.

The CCL of the nesting females ranged from 74.8 to $104.3 \mathrm{~cm}$, the clutch size ranged from 48 to 137 eggs per nest and the egg diameter ranged from 34.2 to $43.2 \mathrm{~mm}$. The number of eggs per nest was signifi-

Table 1. Caretta caretta. Size frequencies of neritic $(\mathrm{N}=10)$ and oceanic $(\mathrm{N}=58)$ loggerhead sea turtles according to their foraging strategy based on $\delta^{13} \mathrm{C}$ and $\delta^{15} \mathrm{~N}$ values in bone. CCL: curved carapace length

\begin{tabular}{|lcc|}
\hline \multirow{2}{*}{ CCL $(\mathrm{cm})$} & \multicolumn{2}{c|}{ Number of females } \\
\cline { 2 - 3 } & Oceanic & Neritic \\
\hline 72 & 0 & 0 \\
74 & 3 & 0 \\
76 & 2 & 0 \\
78 & 13 & 0 \\
80 & 6 & 0 \\
82 & 12 & 0 \\
84 & 11 & 0 \\
86 & 7 & 1 \\
88 & 3 & 1 \\
90 & 0 & 1 \\
92 & 0 & 3 \\
94 & 0 & 1 \\
96 & 0 & 0 \\
98 & 0 & 2 \\
100 & 1 & 1 \\
102 & 0 & 0 \\
\hline
\end{tabular}

Table 2. Caretta caretta. Number of lines of arrested growth (LAGs) recorded in the bone of neritic and oceanic foragers

\begin{tabular}{|lccc|}
\hline & N & Mean & Standard deviation \\
\hline Neritic & 10 & 29.1 & 15.1 \\
Oceanic & 37 & 18.3 & 5.3 \\
\hline
\end{tabular}

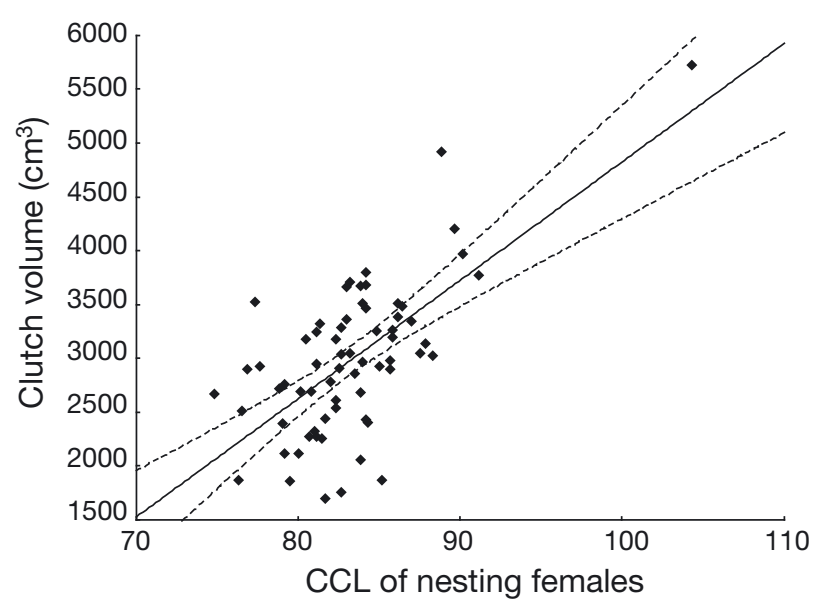

Fig. 4. Caretta caretta. Relationship between clutch volume $\left(\mathrm{cm}^{3}\right)$ and female length $(\mathrm{CCL} \mathrm{cm})(\mathrm{N}=66)$. The regression equation is $y=109.92 x-6168.02$ (Linear regression $\mathrm{R}^{2}=$ $\left.0.44, \mathrm{r}=0.66, F_{1.64}=50.810, \mathrm{p}<0.001\right)$. Dotted lines show confidence bounds

cantly correlated with female size $\left(r_{S}=0.52, t_{66}=4.9\right.$, $\mathrm{p}<0.001$ ) and a residual analysis confirmed that data were homoscedastic. Although no relationship was found between egg diameter and female size $\left(\mathrm{r}_{\mathrm{S}}=\right.$ $\left.0.23, t_{66}=1.9, \mathrm{p}=0.054\right)$ or between clutch size and egg diameter $\left(\mathrm{r}_{\mathrm{S}}=-0.07, t_{66}=0.5, \mathrm{p}=0.557\right)$, clutch volume was significantly correlated with female size $\left(\mathrm{r}_{\mathrm{S}}=0.56, t_{66}=5.4, \mathrm{p}<0.001\right)$. The expected fecundity or reproductive success in terms of expected clutch volume (Fig. 4) was higher for neritic turtles (4137.0 \pm $477.2 \mathrm{~cm}^{3}$ vs. $2893.7 \pm 496.5 \mathrm{~cm}^{3}$ for oceanic turtles, $\left.U_{10,58}=16.0, \mathrm{p}<0.001\right)$. Furthermore, the expected reproductive success was significantly correlated with the $\delta^{13} \mathrm{C}\left(\mathrm{r}_{\mathrm{S}}=0.48, t_{67}=4.4, \mathrm{p}<0.001\right)$ and $\delta^{15} \mathrm{~N}$ values $\left(\mathrm{r}_{\mathrm{S}}=0.55, t_{68}=5.4, \mathrm{p}<0.001\right)$ of the females.

\section{DISCUSSION}

There is growing evidence that adult turtle foraging sites reflect sites that they randomly drifted passively to as juveniles (Hays et al. 2010), a hypothesis that fits well with the results reported here. The dispersal pattern of young loggerhead sea turtles from Cape Verde has recently been estimated from particle tracking models and drifter trajectories (Monzon- 
Argüello et al. 2012) and, according to these techniques, young turtles from Cape Verde initially drift predominantly westward along the southern branch of the North Atlantic gyre (Monzon-Argüello et al. 2012), returning to northwest Africa after several years (Monzón-Argüello et al. 2010).

Dietary analyses of loggerhead sea turtles in the oceanic stage have revealed jelly plankton as their staple food (Bjorndal 1997, Revelles et al. 2007, Frick et al. 2009, Cardona et al. 2012) and a recent study on leatherback sea turtles Dermochelys coriacea revealed low macrozooplankton biomass and poor forage success to the west of Cape Verde compared to the east (Fossette et al. 2010). In this scenario, the immature loggerhead sea turtles returning to Cape Verde after their developmental migration certainly had gained previous knowledge about the existence of a food-poor region west of the archipelago and about the existence of a more productive area east of the archipelago, but were likely unaware of the existence of a food-rich continental shelf $500 \mathrm{~km}$ east of the archipelago.

This prior knowledge, combined with the tendency of immature loggerhead sea turtles to approach their natal beaches for settlement (Bowen et al. 2005) and the limited extension of the continental shelf off the Cape Verde Islands will cause the immature turtles to settle primarily in the oceanic habitats east of the archipelago. Satellite tracking (Hawkes et al. 2006) and stable isotope analysis (present study) confirm that adult loggerhead sea turtles nesting in Cape Verde likely do not forage in the highly oligotrophic waters west of the archipelago, thus indicating some degree of habitat selection at settlement. However, the proportions of neritic and oceanic loggerhead sea turtles nesting in Cape Verde did not depart from those expected from considerations of habitat availability between the archipelago and mainland Africa, although the neritic foragers were older than the oceanic foragers. This result may indicate that the lifespan of the neritic females is longer, or that mortality due to fisheries by-catch is higher in the oceanic zone between Cape Verde and mainland Africa, or that the probability of finding and settling in the African shelf increases over time as the turtles become older.

Tracks of loggerhead sea turtles from Cape Verde include long-distance movements that may allow the oceanic foragers to discover suitable neritic habitats off mainland Africa by chance and re-settle there after some time as oceanic foragers. This mechanism explains why the age of neritic foragers is greater than that of oceanic foragers, although this difference does not represent a true ontogenetic shift.
Rather, the probability of finding the African shelf increases over time as the turtles become older, but not all the adult turtles will settle in the African shelf and oceanic foragers will prevail in the population. Nevertheless, precautions must be taken in the interpretation of skeletochronology results due to bone remodeling and the lack of correction protocols in the absence of samples from young turtles (Parham \& Zug 1997, Piovano et al. 2011).

Although oceanic adult females have been reported from most populations studied to date (Table 3), they are only prevalent in Cape Verde (Hawkes et al. 2006, present study) and Oman (Rees et al. 2010). These 2 regions are characterized by strong upwelling and very high oceanic productivity (Longhurst 1998). Both of these characteristics are certain to facilitate the continued use of these oceanic habitats during the adult stage. However, the data presented here demonstrate that the neritic foragers nesting in Cape Verde are larger and lay more eggs than the oceanic foragers and similar results have been reported from Japan (Hatase et al. 2010). Certainly, the smaller oceanic females could overcome their smaller clutch size by producing more clutches per season and/or by employing the shorter remigration intervals associated with the shorter migration distance between their foraging habitats and their nesting sites, but this hypothesis should be evaluated by future research.

Satellite tracking has confirmed that leatherback sea turtles exploiting oceanic regions with ephemeral patches of food sometimes use Lévy walks during foraging, e.g. when diving, but sometimes range widely and rarely encounter rich prey patches (Hays et al. 2006, Sims et al. 2008). However, adult loggerhead females exhibit much stronger fidelity to their foraging grounds (Broderick et al. 2007, Vander Zanden et al. 2010) that may suggest they follow a search pattern other than Lévy walks and, hence, are less efficient at exploiting oceanic regions unless productivity is very high. Fidelity to foraging grounds and dietary specialization is also evident among the neritic foragers identified here, as they exhibited a much higher variability in their stable isotope ratios than that of oceanic foragers. However, even within oceanic foragers there is remarkable variability, for example a group of 6 turtles were extremely depleted in ${ }^{13} \mathrm{C}$ and ${ }^{15} \mathrm{~N}$ and, hence, likely to exploit the most distant feeding grounds from mainland Africa (Pinela et al. 2010).

Despite these caveats, the overall evidence (Hawkes et al. 2006, present study) suggests that the oceanic habitats east of Cape Verde are profitable 
Table 3. Caretta caretta. Interpopulation variation in the 'neritic-oceanic' foraging dichotomy of adult female loggerhead sea turtles during post-nesting feeding migration. Foraging dichotomy was found to be linked to female size in all cases except in sea turtles from Masirah Island, Sultanate of Oman. $\mathrm{N}=$ number of females studied, $\mathrm{CCL}=$ curved carapace length $(\mathrm{cm}), \mathrm{ST}=$ satellite telemetry, SIA = stable isotope analysis

\begin{tabular}{|c|c|c|c|c|c|c|}
\hline Nesting localization & $\mathrm{N}$ & $\begin{array}{l}\text { Foraging di } \\
{[\mathrm{CC}]} \\
\text { Neritic } \\
\text { foragers }\end{array}$ & $\begin{array}{l}\text { hotomy }(\%) \\
\text { Ocm] } \\
\text { foranic } \\
\text { foragers }\end{array}$ & Method & Source & $\begin{array}{l}\text { Extension of neritic } \\
\text { zone (continental } \\
\text { shelf width) }(\mathrm{km})\end{array}$ \\
\hline $\begin{array}{l}\text { Mediterranean Sea } \\
\text { Greece }\end{array}$ & 69 & 100 & 0 & ST and SIA & Zbinden et al. (2011) & 200 \\
\hline $\begin{array}{l}\text { Pacific Ocean } \\
\text { Japan }\end{array}$ & 102 & $\begin{array}{c}74 \\
{[84.0 \pm 4.0]}\end{array}$ & $\begin{array}{c}24 \\
{[78.4 \pm 3.1]}\end{array}$ & SIA & Hatase et al. (2010) & 100 \\
\hline $\begin{array}{l}\text { North Atlantic Ocea } \\
\text { North Carolina }\end{array}$ & $\mathbf{n}_{12}$ & 100 & 0 & ST & Hawkes et al. (2007) & 50 to 100 \\
\hline Florida & 310 & $\begin{array}{c}46 \\
{[100.5 \pm 5.5]}\end{array}$ & $\begin{array}{c}54 \\
{[97.5 \pm 6.0]}\end{array}$ & SIA & Reich et al. (2010) & 2 to 100 \\
\hline Cape Verde & 9 & $\begin{array}{c}33 \\
{[>93.0]}\end{array}$ & $\begin{array}{c}67 \\
{[<86.5]}\end{array}$ & $\mathrm{ST}$ & Hawkes et al. (2006) & $\begin{array}{c}25 \text { to } 150 \\
\text { (mainland Africa) }\end{array}$ \\
\hline Cape Verde & 72 & $\begin{array}{c}12.50 \\
{[93.1 \pm 5.3]}\end{array}$ & $\begin{array}{c}87.50 \\
{[82.5 \pm 4.6]}\end{array}$ & SIA & Present study & $\begin{array}{c}25 \text { to } 150 \\
\text { (mainland Africa) }\end{array}$ \\
\hline $\begin{array}{l}\text { Indian Ocean } \\
\text { Sultanate of Oman }\end{array}$ & 10 & 20 & 80 & $\mathrm{ST}$ & Rees et al. (2010) & $<5$ to 75 \\
\hline
\end{tabular}

enough to support adult loggerhead sea turtles although the neritic habitats off mainland Africa are more productive. This result and the prevalence of oceanic foragers found in this study imply that most of the adult females nesting in Cape Verde forage in suboptimal habitats. Suboptimality emerges not because better habitats exist somewhere else in the Atlantic, but rather because other individuals in the population use better habitats. Thus, suboptimality is not a biased perception derived from our human knowledge of productivity in the ocean, but the conclusion emerging from the existence of dramatic differences in the fitness of females from the same population.

The probable reason for the prevalence of suboptimal foraging among the loggerhead sea turtles nesting in Cape Verde is that settlement occurs opportunistically east of the archipelago at the end of the developmental migration. Although it is possible that certain turtles shift habitats as they grow, most of the population will forage suboptimally for most of their adult life because they were unaware of the existence of more productive foraging grounds. And natural selection has no capacity to modify this outcome if settlement is an opportunistic process.

Interestingly, high levels of suboptimal foraging are not exclusive to Cape Verde and the loggerhead sea turtles nesting in western Greece (Zbinden et al. 20011) also fit a scenario of suboptimality. Great differences in productivity exist between the foraging grounds used by adult females in the high Adriatic
Sea and the Tunisian shelf, both more productive than the oceanic habitats in between (Bosc et al. 2004). Accordingly, oceanic foragers have not been found in the area and the adult females foraging in the high Adriatic grow larger and lay more eggs than the females foraging in the Tunisian shelf and nesting in the same beach (Zbinden et al. 2011). Nevertheless, approximately half of the females nesting in western Greece forage in the neritic habitats of the Tunisian shelf, at roughly the same distance from the nesting beaches as the more profitable neritic habitats in the high Adriatic Sea. As previously argued, the avoidance of food-poor habitats, combined with opportunistic habitat use by immatures (Casale et al. 2008) and settlement at the end of the developmental migration within suitable areas they have encountered as juveniles (Hatase et al. 2002, Hays et al. 2010) as well as site fidelity to foraging grounds (Broderick et al. 2007, Vander Zanden et al. 2010) provide the most probable explanation for the observed abundance of suboptimal foragers in this population. As in the case of Cape Verde loggerhead sea turtles, suboptimality in the Mediterranean emerges not because in the end there is always a better habitat somewhere else in the ocean. It emerges because turtles nesting in the same beaches but using different feeding grounds differ in fitness and reproductive output.

Suboptimal foraging seems not to be exclusive to loggerhead sea turtles. Leatherback turtles nesting in Papua forage primarily in the highly productive waters off California (Benson et al. 2007) and those 
nesting in the Greater Caribbean exhibit a strong preference for higher latitude, food-rich areas in the north Atlantic (Ferraroli et al. 2004, Eckert 2006, Hays et al. 2006). However, leatherback turtles nesting in Costa Rica forage primarily in a highly oligotrophic region of the southeast Pacific east to Easter Island, but seldom approach the highly productive coastal waters off Peru and Chile (Shillinger et al. 2008). As a consequence, leatherbacks in the eastern Pacific are the smallest in body size (Saba et al. 2008).

In conclusion, immature loggerhead sea turtles are likely picking suitable foraging grounds to settle from the sites they have encountered previously during their developmental migration. Settlement sites may not be optimal simply because turtles do not have knowledge of more suitable areas that they have not encountered during their developmental migration.

Acknowledgements. We thank E. Abella for collecting turtle samples in the field. Samples were imported under CITES permits ES-MA-00059/08C, ES-MA-00483/09C and ESMA-00481/09C.The University of Barcelona provided logistical support, and isotope determinations were made at Centres Científics i Tecnològics. The authors are in debt to J. Correas and Dr. M. Durfort for their help in processing samples for skeletochronology analysis. This project was financed by the Ministerio de Ciencia e Innovación del Gobierno de España (project CGL2009-10017) and awarded a by Conservation, Research and Education Opportunities (CREO, 2010). This research was part of a post-doctoral program supported by the National Research Council of Argentina (CONICET, Programa de Financiamiento Parcial para Estadías Breves en el Exterior para Becarios Internos Postdoctorales del CONICET). The Maptool program was used to produce Fig. 1 (www.seaturtle.org).

\section{LITERATURE CITED}

> Avens L, Goshe LR (2007) Comparative skeletochronological analysis of Kemp's ridley (Lepidochelys kempii) and loggerhead (Caretta caretta) humeri and scleral ossicles. Mar Biol 152:1309-1317

Benson SR, Dutton PH, Hitipeuw C, Samber B, Bakarbessy J, Parker D (2007) Post-nesting migrations of leatherback turtles (Dermochelys coriacea) from Jamursba-Medi, Bird's Head Peninsula, Indonesia. Chelonian Conserv Biol 6:150-154

Bjorndal KA (1997) Foraging ecology and nutrition of sea turtles. In: Lutz P, Musick J (eds) The biology of sea turtles. CRC Press, Boca Raton, FL, p 199-232

> Bjorndal KA, Bolten AB, Bennett RA, Jacobson ER, Wronski TJ, Valeski JJ, Eliazar PJ (1998) Age and growth in sea turtles: limitations of skeletochronology for demographic studies. Copeia 1998:23-30

Bligh EG, Dyer WJ (1959) A rapid method of total lipid extraction and purification. Can J Biochem Physiol 37: 911-917

Bocherens H, Billiou D, Patou-Mathis M, Bonjean D, Otte M,
Mariotti A (1997) Paleobiological implications of the isotopic signatures $\left({ }^{13} \mathrm{C},{ }^{15} \mathrm{~N}\right)$ of fossil mammal collagen in Scladina Cave (Sclayn, Belgium). Quat Res 48: 370-380

Bolten AB (2003) Active swimmers-passive drifters: the oceanic juvenile stage of loggerheads in the Atlantic system. In: Bolten AB, Witherington BE (eds) Loggerhead sea turtles. Smithsonian Institution Press, Washington, D.C

$>$ Bosc E, Bricaud A, Antoine D (2004) Seasonal and interannual variability in algal biomass and primary production in the Mediterranean Sea, as derived from 4 years of SeaWiFS observations. Global Biogeochem Cycles 18: 1-17

Bowen BW, Bass AL, Soares L, Toonen JE (2005) Conservation implications of complex population structure: lessons from the loggerhead turtle (Caretta caretta). Mol Ecol 14:2389-2402

Broderick AC, Glen F, Godley BJ, Hays GC (2003) Variation in reproductive output of marine turtles. J Exp Mar Biol Ecol 288:95-109

> Broderick AC, Coyne MS, Fuller WJ, Glen F, Godley BJ (2007) Fidelity and overwintering of sea turtles. Proc Biol Sci 274:1533-1538

Brown JS (2001) Fit of form and function, diversity of life and procession of life as an evolutionary game. In: Orzarck SH, Sober E (eds) Adaptationism and optimality. Cambridge University Press, Cambridge, p 114-160

Bunn SE, Loneragan NR, Kempster MA (1995) Effects of acid washing on stable isotope ratios of $\mathrm{C}$ and $\mathrm{N}$ in penaeid shrimp and seagrass: implications for food-web studies using multiple stable isotopes. Limnol Oceanogr 40:622-625

Cardona L, Álvarez de Quevedo I, Borrell A, Aguilar A (2012) Massive consumption of gelatinous plankton by Mediterranean apex predators. PLoS ONE 7:e31329

> Casale P, Abbate G, Freggi D, Conte N, Oliverio M, Argano $\mathrm{R}$ (2008) Foraging ecology of loggerhead sea turtles Caretta caretta in the central Mediterranean Sea: evidence for a relaxed life history model. Mar Ecol Prog Ser 372:265-276

- Eckert SA (2006) High-use oceanic areas for Atlantic leatherback sea turtles (Dermochelys coriacea) as identified using satellite telemetered location and dive information. Mar Biol 149:1257-1267

Ferraroli S, Georges JY, Gaspar P, Le Maho Y (2004) Endangered species: where leatherback turtles meet fisheries. Nature 429:521-522

Fossette S, Hobson VJ, Girard C, Calmettes B, Gaspar P, Georges JY, Hays GC (2010) Spatio-temporal foraging patterns of a giant zooplanktivore, the leatherback turtle. J Mar Syst 81:225-234

> Frick MG, Williams KL, Bolten AB, Bjorndal KA, Martins HR (2009) Foraging ecology of oceanic-stage loggerhead turtles Caretta caretta. Endang Species Res 9:91-97

Gilchrist GW, Kingsolver JG (2001) Is optimality over the hill? The fitness landscapes of idealized organisms. In: Orzarck SH, Sober E (eds) Adaptationism and optimality. Cambridge University Press, Cambridge, p 219-241

> Hatase H, Takai N, Matsuzawa Y, Sakamoto W and others (2002) Size-related differences in feeding habitat use of adult female loggerhead turtles Caretta caretta around Japan determined by stable isotope analyses and satellite telemetry. Mar Ecol Prog Ser 233:273-281 
Hatase H, Omuta K, Tsukamoto K (2007) Bottom or midwater: alternative foraging behaviours in adult female loggerhead sea turtles. J Zool (Lond) 273:46-55

Hatase H, Omuta K, Tsukamoto K (2010) Oceanic residents, neritic migrants: a possible mechanism underlying foraging dichotomy in adult female loggerhead turtles (Caretta caretta). Mar Biol 157:1337-1342

> Hawkes LA, Broderick AC, Coyne MS, Godfrey MH, LopezJurado LF, Lopez-Suarez P, Merino SE, Varo-Cruz N, Godley BJ (2006) Phenotypically linked dichotomy in sea turtle foraging requires multiple conservation approaches. Curr Biol 16:990-995

> Hawkes LA, Broderick AC, Coyne MS, Godfrey MH, Godley BJ (2007) Only some like it hot-quantifying the environmental niche of the loggerhead sea turtle. Divers Distrib 13:447-457

> Hawkes LA, Witt MJ, Broderick AC, Coker JW and others (2011) Home on the range: spatial ecology of loggerhead turtles in Atlantic waters of the USA. Divers Distrib 17: 624-640

Hays GC, Hobson VJ, Metcalfe JD, Righton D, Sims DW (2006) Flexible foraging movements of leatherback turtles across the North Atlantic Ocean. Ecology 87: 2647-2656

> Hays GC, Fossete S, Katselidis KA, Mariani P, Schofield G (2010) Ontogenetic development of migration: Lagrangian drift trajectories suggest a new paradigm for sea turtles. J R Soc Interface 7:1319-1327

Humphries NE, Queiroz N, Dyer JRM, Pade NG and others (2010) Environmental context explains Lèvy and Brownian movement patterns of marine predators. Nature 465: 1066-1069

Longhurst A (1998) Ecological geography of the sea. Academic Press, San Diego, CA

Mansfield KL, Saba VS, Keinath JA, Musick JA (2009) Satellite tracking reveals a dichotomy in migration strategies among juvenile loggerhead turtles in the Northwest Atlantic. Mar Biol 156:2555-2570

Marco A, Abella E, Liria-Loza A, Martins S, López O, Jiménez-Bordón S, Medina M., Oujo C, Gaona P, Godley BJ, López-Jurado LF (2012) Abundance and exploitation of loggerhead turtles nesting in Boa Vista island, Cape Verde: the only substantial rookery in the eastern Atlantic. Anim Cons 15:351-360

McClellan CM, Read AJ (2007) Complexity and variation in loggerhead sea turtle life history. Biol Lett 3:592-594

McClellan CM, Braun-McNeil J, Avens L, Wallace BP, Read AJ (2010) Stable isotopes confirm a foraging dichotomy in juvenile loggerhead sea turtles. J Exp Mar Biol Ecol $387: 44-51$

Monzón-Argüello C, Dell'Amico F, Morinière $\mathrm{P}$, Marco A and others (2012) Lost at sea: genetic, oceanographic and meteorological evidence for storm-forced dispersal. J R Soc Interface 9:1725-1732

> Monzón-Argüello C, Rico C, Naro-Maciel E, Varo-Cruz N, López P, Marco A, López-Jurado LF (2010) Population structure and conservation implications for the loggerhead sea turtle of the Cape Verde Islands. Conserv Genet 11:1871-1884

> Newsome SD, Koch PL, Etnier MA, Aurioles-Gamboa D (2006) Using carbon and nitrogen isotope values to investigate maternal strategies in Northeast Pacific otariids. Mar Mamm Sci 22:556-572
Parham JF, Zug GR (1997) Age and growth of loggerhead sea turtles (Caretta caretta) of coastal Georgia: an assessment of skeletochronological age-estimates. Bull Mar Sci 61:287-304

> Pinela AM, Borrell A, Cardona L, Aguilar A (2010) Stable isotope analysis reveals habitat partitioning among marine mammals off the NW African coast and unique trophic niches for 2 globally threatened species. Mar Ecol Prog Ser 416:295-306

- Piovano S, Clusa M, Carreras C, Giacoma C, Pascual M, Cardona L (2011) Different growth rates between loggerhead sea turtles (Caretta caretta) of Mediterranean and Atlantic origin in the Mediterranean Sea. Mar Biol 158: 2577-2587

> Rees AF, Al Saady S, Broderick AC, Coyne MS, Papathanasopoulou N, Godley BJ (2010) Behavioural polymorphism in one of the world's largest populations of loggerhead sea turtles Caretta caretta. Mar Ecol Prog Ser 418: 201-212

> Reich KJ, Bjorndal KA, Frick MG, Witherington BE, Johnson C, Bolten AB (2010) Polymodal foraging in adult female loggerheads (Caretta caretta). Mar Biol 157:113-121

Revelles M, Cardona L, Aguilar A, Fernández G (2007) The diet of pelagic loggerhead sea turtles (Caretta caretta) off the Baelearic archipelago (western Mediterranean): relevance of long-time baits. J Mar Biol Assoc UK 87: 805-813

> Saba VS, Spotila JR, Chavez FP, Musick JA (2008) Bottomup and climate forcing on the worldwide population of leatherback turtles. Ecology 89:1414-1427

Shillinger GL, Palacios DM, Bailey H, Bograd SJ and others (2008) Persistent leatherback turtle migrations present opportunities for conservation. PLoS Biol 6:e171

Sims DW, Southall EJ, Humphries NE, Hays GC and others (2008) Scaling laws of marine predator search behaviour. Nature 451:1098-1102

Snover ML, Hohn AA (2004) Validation and interpretation of annual skeletal marks in loggerhead (Caretta caretta) and Kemp's ridley (Lepidochelys kempii) sea turtles. Fish Bull 102:682-692

Stephens DW, Krebs JR (1986) Foraging theory. Princeton University Press, Princeton NJ

Vander Zanden HB, Bjorndal KA, Reich KJ, Bolten AB (2010) Individual specialists in a generalist population, results from a long-term stable isotope series. Biol Lett 6: 711-714

Wallace BP, DiMatteo AD, Bolten AB, Chaloupka MY, Hutchinson BJ (2011) Global conservation priorities for marine turtles. PLoS ONE 6:e24510

> Watanabe KK, Hatase H, Kinoshita M, Kazuyoshi O and others (2011) Population structure of the loggerhead turtle Caretta caretta, a large marine carnivore that exhibits alternative foraging behaviors. Mar Ecol Prog Ser 424: 273-283

Zbinden JA, Bearhop S, Bradshaw P, Gill B, Margaritoulis D, Newton J, Godley BJ (2011) Migratory dichotomy and associated phenotypic variation in marine turtles revealed by satellite tracking and stable isotope analysis. Mar Ecol Prog Ser 421:291-302

Zug GR, Wynn AH, Ruckdeschel C (1986) Age determination of loggerhead sea turtles, Caretta caretta, by incremental growth marks in the skeleton. Smithson Contrib Zool 427:1-34 